\title{
A date with Tylman Susato: reconsidering the printer's editions
}

\author{
Martin Ham
}

In 1542, Antwerp saw the first dated books of polyphonic music to be produced in the Low Countries from moveable type: a book of motets from Vissenaecken's press, and a collection of Benedictus Appenzeller's chansons printed by Loys and Buys. Despite ambitious plans, neither of these enterprises established itself; no other music from them is known. ${ }^{1}$ Where they seemingly failed, Tylman Susato - composer, scribe, instrumentalist and music printer - certainly succeeded. Over the course of nearly twenty years from 1543, he issued no fewer than fifty-five collections, reprinting most of them, some more than once. Accordingly, Susato has attracted significant scholarly interest. ${ }^{2}$ Nevertheless, uncertainties remain about aspects of his output, particularly the collections reprinted with false dates. This chapter reconsiders Susato's Libri ecclesiasticarum cantionum, the chanson collections, and the impetus behind their reissue. This re-examination provides a fuller picture of Susato's commercial activities. There is comparatively little overlap of typographical materials between the motet and chanson books, and so it is more convenient to discuss them separately. Founts and changes of individual sorts help materially in establishing likely patterns of production; details are provided in Appendix 7.1.

\section{The Libri ecclesiasticarum cantionum}

Susato issued the fourteen Libri ecclesiasticarum cantionum in the 1550s. (I shall refer to them as EC 1-14; for all other abbreviations, see Appendix 7.2.) EC 13 is lost; the surviving books contain around 250 motets by some sixty composers from the major to the otherwise now unknown. They form a treasury of the mid-century Netherlands motet. ${ }^{3}$ The books are of uniform size overall. EC 1-4 are for four voices; each partbook comprises five gatherings of four leaves in oblong quarto. EC 5-12 and 14 are for five voices, but have only four gatherings per voice each, so that every collection is formed of twenty sheets of paper, that is, one sheet per gathering.

In her study of Susato, Ute Meissner drew attention to apparent anomalies of dating and variants on the title pages of exemplars held in three libraries. ${ }^{4}$ She advanced no detailed explanation for these anomalies, but considered it likely that the entire series was first issued in 1553, with one or more subsequent editions. Meissner's observations were valid as far as they went. Howard Mayer Brown considered that they revealed a sizeable problem that needed clarification. ${ }^{5}$ The generally accepted alternative view is that Susato printed these books over a period extending into 1558, reprinting most titles in the series in those same years under their earlier dates. In other words, there was a hidden and partial second edition. The most recent overview of Susato's printing activities is given in Table 7.1. ${ }^{6}$ 
Table 7.1 Current dating of the EC series

\begin{tabular}{lll}
\hline & RISM B/I sigla & Dating \\
\hline EC $1-3$ & $1553^{8-10}$ & 1552 \\
EC 4 & $1554^{8}$ & 1554 \\
EC 5 & $1553^{12}$ & 1552 \\
EC 6-8 & $1553^{13-15}$ & 1553 \\
EC 9 & $1554^{9}$ & 1554 \\
EC 10-11 & $1555^{8-9}$ & 1555 \\
EC 1-11 ex. 4 & & $1555-1556$ hidden second edition \\
EC 12 & $1557^{3}$ & $1557(E C$ 13 lost but 1557) \\
EC 14 & $1553^{16}(\mathrm{Q})+1557^{4} / 1558^{3}$ & $1557 / 58$ \\
\hline
\end{tabular}

It has been argued that the incentive for a second edition of these motet books was the meeting of the Order of the Golden Fleece at Antwerp in January 1556. The many visitors, some perhaps staying for an extended period, would have provided a ready market. ${ }^{7}$ Attractive though this hypothesis is, variants and anomalies raise questions about their nature and significance. Up to now, they have largely been explained as errors, typesetting differences, accidents or the result of atypical production methods. ${ }^{8}$ However, these explanations seem not to correspond with typographical evidence provided by the books.

The first uncertainty is whether Susato began the series in 1552, as indicated in Table 7.1. The only dedication contained in any volume in the series appears in EC 1, addressed to Antoine Perrenot, Emperor Charles V's counsellor and secretary of state. It is dated 10 March 1553 stilo Romano, that is, with the year starting on 1 January, rather than at Easter or Lady Day (Annunciation, 25 March). ${ }^{9}$ No exemplars of EC 1-3 or 5 dated 1552 have been recorded, and there is nothing overt in those exemplars I have seen to verify that year. In addition, the features of the first edition of EC 1 of 1553, as we shall see below, also show that it was without doubt the first of the series printed. I therefore work on the assumption that Susato started issuing these collections in $1553 .^{10}$

When we are trying to establish the sequence of publication, two typographical markers help us to identify those books that were most likely printed in 1556 at the earliest, whatever their ostensible date. In 1556-1557 Susato issued his first four books of Souterliedekens, most set by Clemens non Papa, with a few by Susato himself. As in Simon Cock's earlier monophonic version, these covered the complete psalter, together with biblical canticles and hymns. Susato presumably would have wanted to offer all four books as a set to those who could afford them. Given that the last of the series is dated 1557, the others are likely to be from the latter end of 1556. These four books display two distinctive sorts within Susato's Basel italic: lower case ' $v$ ' and ' $w$ ' (shown in Appendix 7.1). The ' $w$ ' was useful only for the Dutch vernacular collections; it was needed for neither Latin nor French texts. When he came to print the first three volumes of his Musyck boexkens in 1551 (abbreviated here as $M B$ ), Susato still had yet to obtain one. Instead, he used a combination of ' $v$ ' and / or ' $\mathrm{u}$ ' on their title pages, and in the indexes of MB 1-2. (The headers and texts in these books were set in pica italic.) However, in these new books almost every header, now set in Basel italic, required it. To judge from their design, these two sorts constituted a pair created by the same punchcutter. Susato would have had no use for the ' $w$ ' in any intervening edition, and already had a serviceable ' $\mathrm{v}$ ', and so we can assume that he acquired the sorts while preparing for the 1556-1557 SL 1-4 collections. Any other book containing either or both of these sorts is therefore likely to have been printed around mid-1556 at the very earliest. Since the ' $v$ ' is extremely common, it makes a particularly useful indicator. 
Further details support the existence of a dividing line in 1556 between the use of old and new forms. The new ' $\mathrm{v}$ ' is not present in those sets of EC partbooks stamped with the years 1555 (US-Lu) and 1556 (D-Kl, except for quinta pars; D-B(i)) on their original bindings. Neither does it appear in any part of the 1555 editions of EC 10-11, TS 14 (Lassus' 'op. 1') of the same year, or any of those motet or chanson collections that can be shown on typographical grounds to precede them (see below). In the other direction, the new ' $\mathrm{v}$ ' sort entirely replaced the old one in all of Susato's editions dated 1556 onwards, or which can be dated later on the basis of other evidence, such as the last edition of the chanson collections. Within the EC series itself, the distinction by old or new ' $v$ ' sort is also marked by consistent differences in the details of title pages (see Figure 7.1). One obvious to the eye, for example, is that those with the old sort have 'uocum' in large Roman type, while
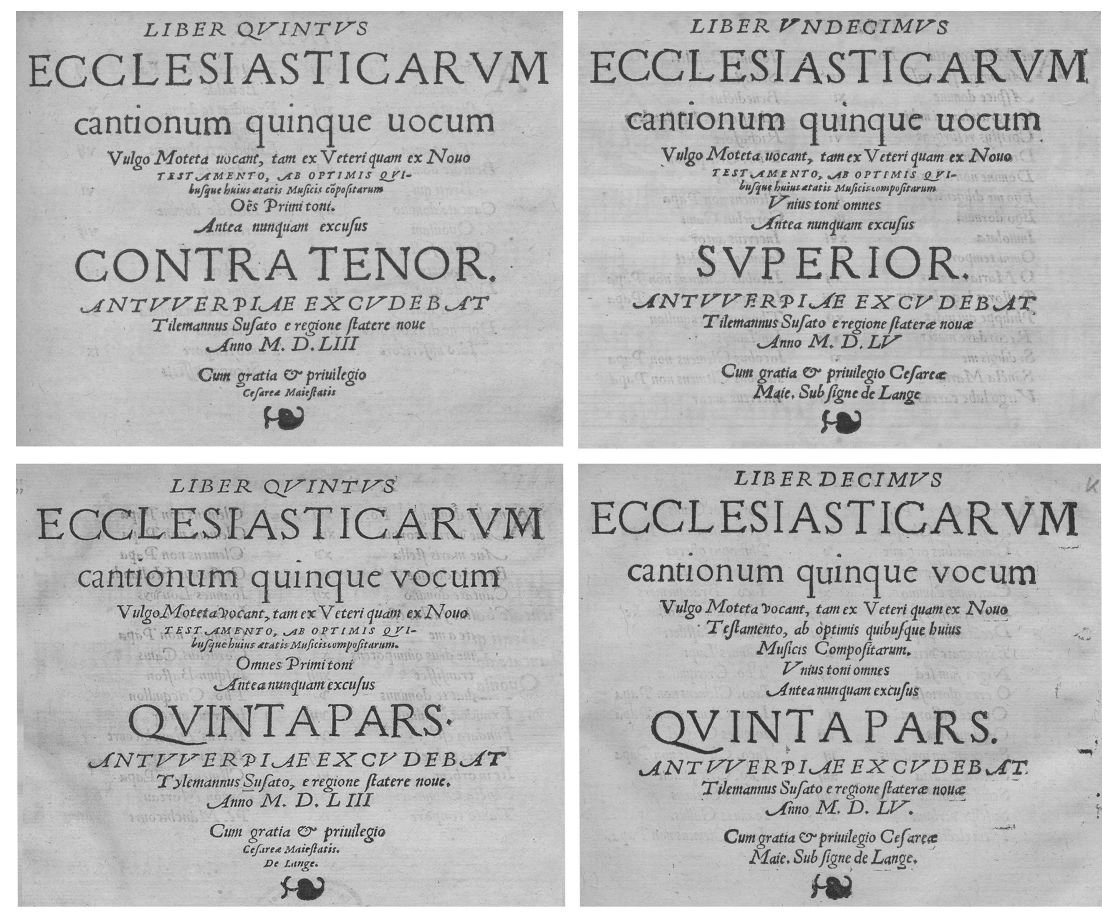

Figure 7.1 Examples of title pages.

(a) A(i) 1553: Liber quintus ecclesiasticarum cantionum quinque vocum ... Quinta Pars (Antwerp: Susato, 1553).

Source: Universitätsbibliothek Kassel, Landesbibliothek und Murhardsche Bibliothek der Stadt Kassel, $4^{\circ}$ Mus. $107[2$.

(b) B(i) 1555: Liber undecimus ecclesiasticarum cantionum quinque vocum ... Superior (Antwerp: Susato, 1555).

Source: Universitätsbibliothek Kassel, Landesbibliothek und Murhardsche Bibliothek der Stadt Kassel, $4^{\circ}$ Mus. $107[1$.

(c) B(ii) 1557: Liber quintus ecclesiasticarum cantionum quinque vocum ... Quinta Pars (Antwerp: Susato, '1553' [actually 1557]).

Source: Universitätsbibliothek Kassel, Landesbibliothek und Murhardsche Bibliothek der Stadt Kassel, $4^{\circ}$ Mus. $107[5$.

(d) C 1558: Liber decimus ecclesiasticarum cantionum quinque vocum ... Quinta Pars (Antwerp: Susato, '1555' [actually 1558]).

Source: Universitätsbibliothek Kassel, Landesbibliothek und Murhardsche Bibliothek der Stadt Kassel, $4^{\circ}$ Mus. $107[5$. 
the others have 'vocum', in line with the 1557 and 1558 partbooks of EC 12 and 14. The occasional use of the ' $w$ ' sort in composers' names conforms to the same pattern.

A further point concerns Susato's use of standing type. To explain variants as compositors' inconsistencies or errors supposes that each title page within a collection was composed individually. However, that was not Susato's practice. Without exception, his other collections - leaving aside those few too incomplete for comparisons to be made - show that essentially a single setting of type was used for the title page, and the index where this is separate, as in the large majority of his books. Sometimes a dedication or other prefatory matter required restructuring of the opening leaf of an individual voice, but even then the compositor reused a greater or lesser element of the available composed type as was convenient. Apart from such instances, only voice names had to be changed. Keeping type standing for reuse significantly reduced the time - and therefore the cost - taken to compose, proof and correct those pages. Susato frequently went further, using large portions of standing type for the title pages of several books within a series. This was even easier when he standardised their layout to a degree, as in the $E C$ collections. ${ }^{11}$ If then a printer reset a title page for some reason during production, the new version would flow through to the next voice and possibly to the next book. Put another way, it is not feasible to have a reset title page within a series of otherwise identical title pages. ${ }^{12}$

Since the title pages and indexes in the EC series appear on opposite sides of the opening folio, they are part of the outer and inner formes respectively. As far as the printing process for a sheet is concerned, these are entirely separate events. If a problem with the title page or index had arisen, there would have been no need to reset the other unless the whole sheet was being reset, whether as a cancel (a leaf reset to correct an error) or for some other reason. That provides a convenient means to check whether we are dealing in a given case with a separate state, a reset sheet or a different edition. However, reset sheets are an unlikely explanation for variants. The high cost of paper as a proportion of the direct cost base makes cancels something an experienced printer such as Susato would take pains to avoid, as they would reduce his realisable profit. Resetting sheets for other reasons would similarly cost time and money. ${ }^{13}$ As to the explanation of differences of publication year as 'accidents', the loss of an individual piece of type is a theoretical possibility in some cases - if, for example, it was pulled out of the forme during inking - but not all. Again, Susato's use of standing type means that title pages and indexes in the various partbooks of the same publication should otherwise be identical. Although there is comparatively little common material within a set of partbooks beyond the opening leaf, Susato employed vertical setting, that is, setting an individual gathering in one voice - usually the superior then the same gathering in each of the remaining voices. In this way, some portions of composed type could be shared between partbooks, for example, headers, folio numbers, signatures and sometimes portions of underlaid text. ${ }^{14}$

Three examples illustrate different aspects of these observations. ${ }^{15}$ First, let us examine EC 10. On the face of it, all five voices of this book are dated 1555. However, the contratenor of some copies gives the date as M.D.LIIII, while the other partbooks give it as M.D.LV (see Figure 7.2). With these two ways of expressing the year, there can be no question of an accident during printing. Even a cursory inspection shows that the title page of the contratenor was not printed from the same setting of type as that used for the remaining voices. ${ }^{16}$ Closer examination shows that the final II of M.D.LIIIII was an addition made after the sheet had been printed, using a piece of type as a stamp, as shown by the difference in inking and the variations in alignment between surviving copies. Thus, sheets bearing the year 1553 were altered to make the purchaser believe that they belonged to the later 


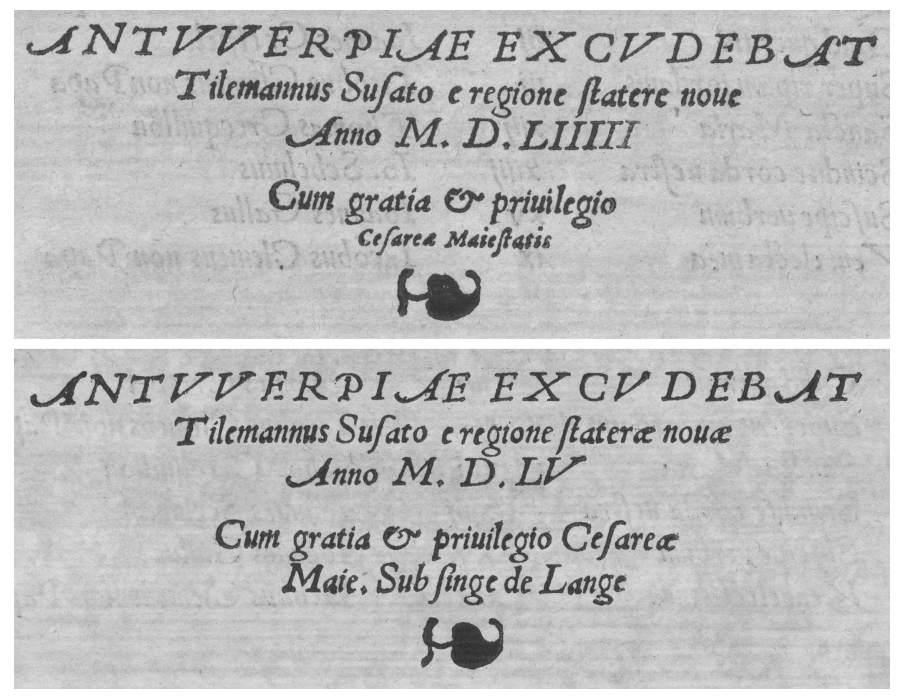

Figure 7.2 Comparison of dates in EC 10: Liber decimus ecclesiasticarum cantionum quinque vocum (Antwerp: Susato, 1555).

(a) contratenor [actually 1553].

Source: Universitätsbibliothek Kassel, Landesbibliothek und Murhardsche Bibliothek der Stadt Kassel, $4^{\circ}$ Mus. $107[2$.

(b) other voices except quinta pars (superior illustrated).

Source: Universitätsbibliothek Kassel, Landesbibliothek und Murhardsche Bibliothek der Stadt Kassel, $4^{\circ}$ Mus. $107[1$.

Note: In the tenor, bassus and quinta pars, 'singe' has been corrected to 'signe'.

edition, although it may be doubted that Susato made this adjustment. ${ }^{17}$ The indexes also vary significantly; moreover, the headers and folio numbers of the rest of the gathering are set in pica italic, like Susato's earlier editions, and not in Basel italic, like the remaining portions. The differences only extend, though, to the first sheet. However, in one exemplar (D-As), the entire contratenor book, including the first gathering, comes from the same edition as the remaining voices. The musical readings in the first gathering of this exemplar disclose no significant differences that might lead us to consider one version as faulty and the other a cancel. Furthermore, its existence confirms that Susato indeed printed the appropriate sheet at the time in 1555, using the same type as for the other voices. Finally, the 1555 title page of EC 10 was reused for EC 11, printed the same year. This demonstrates that the type for the title page was not distributed back into the case or reset, but was kept standing.

EC 12 (1557) shows a similar combination of features; once again, the contratenor has an aberrant gathering. In this instance, though, no attempt was made to adjust the date. Pulled type or similar accident can be ruled out. M.D.LVII cannot become M.D.LIII by the loss of an individual piece, nor - as the alignment makes clear - by the insertion of an incorrect piece in substitution. Nor would pulled type account for the many other varying details on the title page. Two additional points may be noted. First, the aberrant gathering uses the earlier ' $v$ ' sort in Basel italic, while the remaining gatherings, in line with their date, use the form introduced in 1556, as well as the ' $\mathrm{w}$ ' sort in the name of one composer ('Hauweel'). Second, the contents of the book were adjusted between editions. Two motets listed in the 
1553 index were replaced with others, and the old titles simply crossed through by hand: Gallus' Ecce panis angelorum was replaced by Willaert's Creator omnium, while Barbion's Girum coeli took the place of Vaet's Quid Christum. A four-voice setting of the latter text, also by Vaet, was included in EC 3, but there is no way of knowing if these were different settings, or if the four-voice original was included in this five-voice collection, perhaps with an additional voice. Aside from the indexes, the change of the contents is not obvious from the remaining exemplars, simply because the works in question were not in the opening gathering. A further gathering also seems to be taken from a different edition: gathering $\mathrm{C}$ of the superior does not fit with any of the other voices, with significant variants in both formes. As has been noted, it was Susato's general practice to print the superior first; this can be seen in the mistaken inclusion on fol. $4^{\mathrm{r}}$ of the tenor and quinta pars of that voice name. The fact that the superior is anomalous is noteworthy, as is the omission of detail in the lower voices, as that is the voice from which the others were usually copied, and from which some type was always reused. Perhaps more conclusively, one folio number in sheet $C$, fol. xii was misprinted, and although attempts were made to correct it, the original misprinted number clearly used the earlier form of Basel italic ' $\mathrm{v}$ ', unlike the remainder of the leaves in the partbook. ${ }^{18}$

The variants taken together (see Table 7.2) show that this sheet must have been printed before 1557. However, the headers of this gathering are in Basel italic, and not the pica italic of the opening gathering of the contratenor. It cannot belong with the edition that that sheet represents. Rather, these two sheets are remnants of two separate editions, printed prior to the main portion of the surviving books dated 1557.

EC 14 contains perhaps the best-known mixture of dates, highlighted by the fact that it has been given three RISM sigla. Two of these sigla (RISM $1557^{4} / 1558^{3}$ ) refer to a single edition; Susato printed it over the year-end, and adjusted the year from 1557 to 1558 after the superior had been completed. The title pages for the four voices dated $1557 / 58$ are otherwise identical. All three surviving exemplars of the quinta pars are, like EC 10 and 12, dated 1553 (RISM 1553 ${ }^{16}$ ). Yet again, the title pages, indexes and typographical details and sorts allow us to establish that this initial gathering is from a separate edition. It has been asserted, though, that the date 1553 given in the quinta pars was caused by the accidental loss of the ' $\mathrm{V}$ ' in 'M.D.LVIII', resulting in the misleading date 'M.D.LIII'. ${ }^{19}$ There are good reasons to reject this view. First, the title page of the quinta pars shows no gap where the 'lost' letter ' $V$ ' could have been pulled. Practical experience shows that it is not possible in a locked forme to adjust the type to close such a gap. If the pressmen did anything following the accidental pulling of a ' $\mathrm{V}^{\prime}$, it was surely to replace it in the resulting gap rather than unlocking the forme and moving the 'III' to the left. Second, even if one were to construct

Table 7.2 Headers of the third gathering of EC 12

\begin{tabular}{lll}
\hline Sig. & Superior & All other voices \\
\hline $\mathrm{C}^{\mathrm{r}}$ & Superius Secunda Pars & [voice] Secunda Pars. \\
$\mathrm{C}^{\mathrm{v}}$ & Ieronimus Vinders & Iero. Vinders \\
$\mathrm{C} 2^{\mathrm{r}}$ & Secunda Pars. & Secunda Pars. \\
$\mathrm{C}^{\mathrm{v}}$ & Lucæ xxij Nico. Gombert & Ni. Gombert. \\
$\mathrm{C}^{\mathrm{r}}$ & Secunda Pars & Secunda Pars \\
$\mathrm{C} 3^{\mathrm{v}}$ & In festo Purificationis HauVueel & Io. Hauweel. \\
$\mathrm{C} 4^{\mathrm{r}}$ & Secunda Pars & Secunda Pars. \\
$\mathrm{C} 4^{\mathrm{v}}$ & Christianus Hollandere & Christianus Hollandere \\
\hline
\end{tabular}


a hypothetical scenario in which this sheet in the last voice had to be reset (to explain its variants), it would be impossible for it to mirror exactly the pages printed from standing type from sheets in other books; yet it does, and uses the earlier Basel italic ' $v$ ' form. There can be no doubt the date of 1553 in the contratenor was intentional. ${ }^{20}$

As with EC 12, there was also some change of content in EC 14: Homo quidam by Phinot replaced Gaudent in coelis by Havericq. Unlike the manual crossing-through found in EC 12, the index here was altered by means of a pasted slip in Susato's own fount with the distinctive new ' $v$ ' sort (Figure 7.3). Havericq's motet had already been printed in EC 12, and so it appears that Susato himself was correcting an error of duplication in an earlier edition. The deleted motet and its replacement did not fall within that first gathering, and so there was no greater problem to fix than patching the index.

Leaving aside the late hidden edition (see Table 7.3), further aberrant first gatherings are found in each of the exemplars of EC 5-9 dated $1553 .{ }^{21}$ Typographical details similar to those outlined above preclude any of these sheets being a cancel, or having been reset for any other reason. Moreover, when their title pages are considered as a group with those of EC 10, 12 and 14, they are found to share an identical layout and typesetting, including exactly the same form of privilege. Moreover, the headers and folio numbers were printed in pica italic, Susato's style in his previous $M B 1-3$, not in the Basel italic that he used in all the EC series from 1554 at the latest. Several aberrant sheets beyond the initial gatherings can be identified in books other than EC 12. One seems peculiar to a single surviving exemplar (in GB-Lbl): here, the final gathering (E) in the bassus partbook of EC 4 comes from a later edition, while the original sheet for the edition is bound in the bassus partbook of EC 7 from the same set of books. ${ }^{22}$ An even greater degree of confusion can be seen in EC 6. In three of the voices, all the surviving copies show the same mixture of sheets from two editions. The respective gatherings can be distinguished by the founts used for the

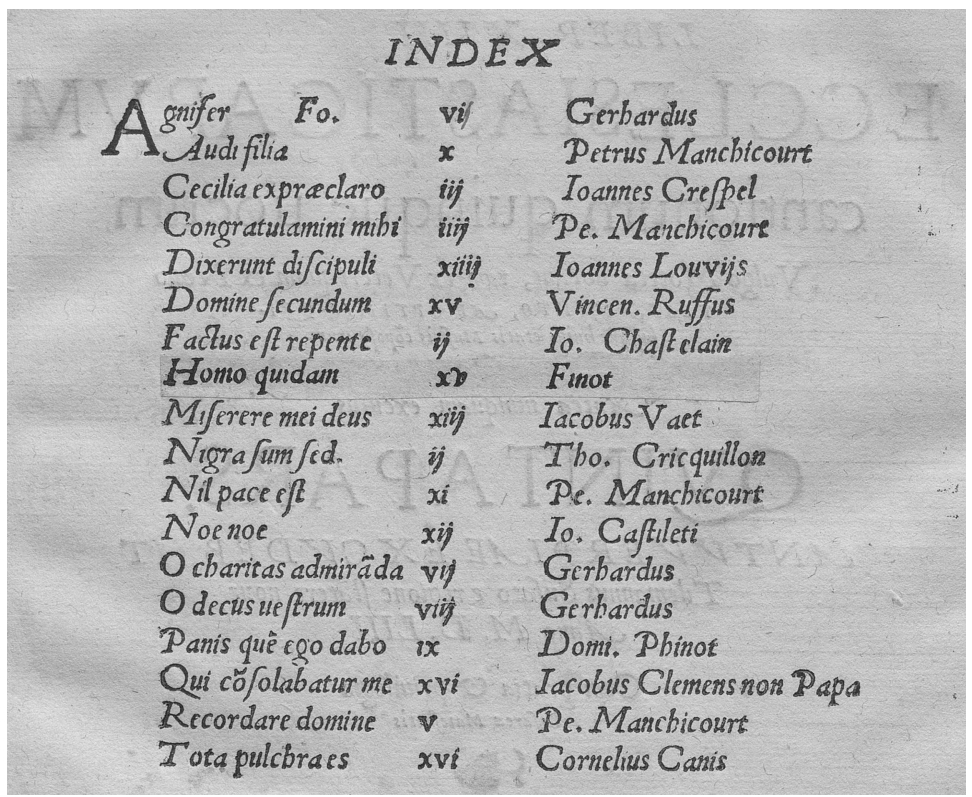

Figure 7.3 Index of EC 14, quinta pars, showing pasted slip correction in Susato's fount: Liber XIIII ecclesiasticarum cantionum quinque vocum ... Quinta Pars (Antwerp: Susato, 1553), A1v.

Source: Uppsala University Library, Utl.vok.mus. i tr. 535-538. 
Table 7.3 Summary of probable editions of the EC series

\begin{tabular}{llll}
\hline Edition & Evidence for & Possible extent & Year \\
\hline $1(\alpha)$ & $1-10,12,14$ & $1-14$ & 1553 \\
$2(\beta$ part hidden?) & $5-8,12$ & $1-14$ & $1553-1554$ \\
$3(\gamma)$ & $4,9-11$ & $1-11$ & $1554-1555$ \\
$4(\delta$ hidden $)$ & $1-8$ & $1-8$ & $1556-1557$ \\
$3(\gamma$ continued $)$ & 12,14 & $12-14$ & $1557-1558$ \\
$4(\delta$ hidden, cont. $)$ & $9-11$ & $9-14$ & 1558 \\
\hline
\end{tabular}

headers as well as by their content. Only a single gathering (B) is consistent between all the voices. In each case there is agreement in the headers of the respective editions, except gathering A of the contratenor, which is unique. It seems then that the surviving exemplars were made up of sheets from two editions, five from one and fifteen from the other, put together almost at random.

Without such differences in the founts used for headers and signatures, it is more difficult to identify aberrant gatherings beyond the first one, especially where a single gathering in all voices might have been taken from a different edition from the rest. However, one instance seems likely. ${ }^{23}$ The first gathering of the contratenor book in EC 5 is aberrant; this is yet another example of a title page and index in one partbook being distinct from those of the other voices (Figure 7.4 shows the indexes). The respective gatherings, though, also differ in a basic element of the layout. In all voices apart from the contratenor, the compositor inserted blank staves in gatherings $\mathrm{A}$ and $\mathrm{B}$ where the musical text was too short to fill the page, as was usual. However, in gatherings $C$ and $D$ he did not; in that respect these gatherings are the same as the aberrant contratenor. This distinction is also found in the aberrant gatherings of EC 8-9, 12 and 14, as well as all voices of EC 2-3 (the relevant sheets of $E C 7$ and 10 are full). This therefore appears to have been a characteristic of early house style, found in certain titles; later EC books consistently included empty staves. As such, it is likely that these sheets all belong to a single edition. For EC 5, the individual gatherings are internally consistent, apart from gathering $\mathrm{A}$ in the contratenor; the book was thus likely compiled from sheets from two editions, but collated in a different manner from EC $6 .^{24}$

Typographically, the surviving exemplars and aberrant sheets fall into two distinct groups. On one hand are those which precede EC 10 (1555), and which share a large amount of standing type on their title pages. These are indicated as A(i-iii) in Appendix 7.3, where the overall position is summarised, and the make-up of exemplars described where known. On the other hand are the editions from EC 10 of 1555 onwards (indicated as B-C in Appendix 7.3); these are more varied in their typesetting (see Figure 7.1). EC 9 (A(iii) in Appendix 7.3), as implied by its date of 1554, is undoubtedly the last book of those printed within these first two years. The top left corner of the ornamental block initial for the bassus partbook sustained damage during the print run, not yet evident in any of the other books of this group. ${ }^{25}$

A number of features suggest that those listed under A(i) constitute the first edition. EC 1 has minor errors and variants between the title pages of the various partbooks, and an incorrect explicit altered by hand.$^{26}$ The title page of EC 2 carried forward the format of the tenor partbook of EC 1, with the small alteration of NVNQVAN to NVNQVAM. From EC 3 onwards, the phrase Antea nunquam excusus was set in Basel italic rather than Roman type. This is followed in all later editions, with the exception of the late hidden edition, which 


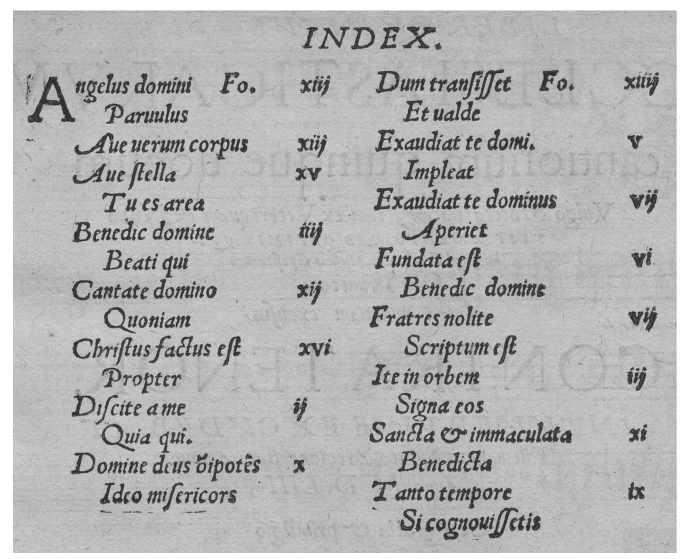

\begin{tabular}{|c|c|c|}
\hline \multicolumn{3}{|c|}{ INDEX. } \\
\hline A ngelus domini & xiij & Clemensnon Papa \\
\hline 1 Aue uerum corpus & xii) & Clemens non Papa \\
\hline Aue maris fella & $x v$ & Clemens non $\boldsymbol{P}_{\text {apa }}$ \\
\hline Benedic domine & iii) & Criftianus bollande \\
\hline Cant ate domino & $x i j$ & Ioannes Louvijs \\
\hline Chriftus factus eft & $x v i$ & Incertus autor \\
\hline Difcite a me & yj & Clemens non $\boldsymbol{P}_{\text {apa }}$ \\
\hline Domine deus onnipotês & $x$ & Cornelius Canis \\
\hline Dumtranfifet & xiiij & Io. Bafton \\
\hline Exaudiat te dominus & v & Tho. Cricquillon \\
\hline Exaudiat dominus & $v i p$ & Incertus autor \\
\hline Fundata eft & vi & Pe. Mancbicours \\
\hline Fratres nolite & $\mathbf{v i j}$ & Incertus autor \\
\hline Ite in orbem & (ii) & Clemens non $\mathrm{P}_{\text {apa }}$ \\
\hline Sancta O imaculata & $x i$ & Symon moreans \\
\hline Tento tempore & $i x$ & Pe. Manchicours \\
\hline
\end{tabular}

Figure 7.4 Indexes of EC 5: Liber quintus ecclesiasticarum cantionum quinque vocum ... Quinta Pars (Antwerp: Susato, 1553).

Source: Universitätsbibliothek Kassel, Landesbibliothek und Murhardsche Bibliothek der Stadt Kassel, $4^{\circ}$ Mus. $107[2$.

(a) A(i) contratenor.

Source: Universitätsbibliothek Kassel, Landesbibliothek und Murhardsche Bibliothek der Stadt Kassel, $4^{\circ}$ Mus. $107[2$.

(b) A(ii) other voices except quinta pars (bassus illustrated).

Source: Universitätsbibliothek Kassel, Landesbibliothek und Murhardsche Bibliothek der Stadt Kassel, $4^{\circ}$ Mus. $107[4$.

copied quite slavishly. A designation of the mode was added from EC 5. Oēs Primi toni, a phrase found in EC 5-7, was clearly printed from the same block of type, transferred with the rest of the title page. However, this designation was incorrect for the motets of EC 7, an error which Susato amended in later editions of this book. The style of headers, set in pica italic, in all the surviving sheets from this edition, is unchanged from $M B 1-3$. Within this first edition, Susato's compositor experimented in search of the best format for the index before he finally fixed upon a solution. The index of EC 1 again mirrored those in the earlier $M B 1-2$ ( $M B 3$ is not relevant), giving the partes of each work but no attribution. By the time he came to set EC 6, he had settled on the form used in later editions, which gave text incipits and composers. ${ }^{27}$ Susato would have found, too, that this simplified form of presentation - one that subjectively seems the most useful for the singer or reader - was also the easiest, and therefore the most economical to compose. ${ }^{28}$

Most of the standing type for those books and sheets listed under A(ii) was still that used from the tenor of EC 1 until the surviving quinta pars of the first edition of EC 14 . However, these books display a slightly modified privilege line, again dated 1553. It is not clear whether this implies the existence of a new privilege. Given the length of the series, several listed under A(ii) reprinted with the year 1553 may well have been issued in $1554 .{ }^{29}$ Those listed under A(iii) have the identical privilege but a date of 1554 . As the date formed part of the standing type, any alteration to it must have been intentional. Had EC 4 been printed before those later in the series listed under A(ii), then the year would necessarily have been changed twice. EC 4 also has a comma after 'Susato', introduced into the standing type during the second printing of EC 7; this comma appears on none of the title pages of the first edition, nor on those of EC 5-6 of the second edition. ${ }^{30}$ It therefore seems probable that EC 4 and 9 of 1554 were printed after the second edition of EC 8; in other 
words, they are part of a third edition. The change in house style - from pica italic in the first edition and EC 5 of the second edition, to Basel italic for headers, folio numbers and signatures in the second edition of EC 6 - again allows us to place EC 4 later, not as part of the same sequence, as it too uses Basel italic for these elements. This evidence, along with the aberrant sheet from EC 12 of 1557, allows us to posit the existence of two prior editions. It thus seems likely that all the books truly dated from 1554-1558 form part of a third edition produced over an extended period.

Although the editions listed under B-C in Appendix 7.3 form a less coherent group typographically than those listed under $\mathrm{A}$, a comparison of standing and reset type shows overlapping concordant details that establish the sequence in which these books were printed..$^{31}$ A significant proportion of the type on the common title page of used for EC $10-11^{\gamma}$ was taken forward to $E C 1^{\delta}$. Yet because the latter was copied from the first edition, that is, before Susato had standardised his layout, part was changed more to resemble its model. ${ }^{32}$ At the same time, 'uocum' in large Roman type on the title page was altered to 'vocum', and the newer Basel italic ' $v$ ' replaced the older throughout. Both these changes are consistent in all the later EC books. ${ }^{33}$ It is unlikely therefore that $E C 1^{\delta}$ was printed earlier than mid-1556, but no closer approximation is possible at present. Susato seems to have printed $E C 3^{\delta}$ next, rather than $E C 2^{\delta}$ as one might have expected. While he reversed the few atypical elements of the title page of $E C 1^{\delta}$, he still took over some lines as they stood. Even so, the changes go beyond those strictly necessary to recreate his more usual format; thus it is probable that their printing was not consecutive. ${ }^{34}$ The resetting of one line of text is of particular evidential value: the phrase 'ANTVVERPIAE EXCVDEBAT' acquired a number of readily distinguishable peculiarities unlikely, if not impossible, to have been replicated by chance, and certainly not time after time (see Figure 7.5). Its specific mixture of characteristic elements can be traced from EC $3^{\delta}$ through EC $12^{\gamma}, E C 2$ and $4-8^{\delta}$, to EC $14^{\gamma}$ of $1557 / 58$. EC $3^{\delta}$ was undoubtedly followed closely by EC $12^{\gamma}$ of 1557 . Much of its title page was printed from the same type, suggesting no break for other work. ${ }^{35} E C 3^{\delta}$ was therefore most probably printed in 1557 too.

It seems that something then interrupted the reprinting of this series, as a considerable portion of the type was composed anew after EC $12^{\gamma}$, or in some instances perhaps simply respaced. ${ }^{36}$ For example, the features of the main title line in those titles printed between $E C 11$ and $E C 12^{\gamma}$ (by way of EC 1 and $3^{\delta}$ ) disappear. The reset lines pass from EC 2 to 4 and EC $5^{\delta}$ before other minor alterations become apparent. ${ }^{37}$ Although the further changes are small, they are enough to suggest that the standing type had been cannibalised to an extent for other publications printed in the interim. This typesetting then remains stable from $E C$ 6 to $E C 8^{\delta}$. The now lost EC 13 must have been printed at some point around this time, but there are still significant elements in common between $E C 8^{\delta}$ and $E C 14^{\gamma} .{ }^{38}$ As a result, EC 2 and $4-8^{\delta}$ can all confidently be assigned to 1557 .

The title page of $E C 9^{\delta}$, although the same in overall style as previous books, was wholly reset, while those of $E C 10-11^{\delta}(\mathrm{C})$ differ from all others; here the compositor simplified their composition by reducing the variety of founts used. All three are bound together in

\section{ANTVVERPI AE EXCVDEBAT}

Figure 7.5 Example of type transferred from EC $3^{\delta}$ to EC $14^{\gamma}$ : Liber XIIII ecclesiasticarum cantionum quinque vocum ... Superior (Antwerp: Susato, 1553), $\mathrm{A} 1^{\mathrm{r}}$.

Source: Uppsala University Library, Utl.vok.mus. i tr. 535-538. 
an exemplar (D-Kl Quinta), the binding of which is dated 1557, but it is impossible that they could have been produced within the period covered by EC $1^{\delta}-14^{\gamma}{ }^{39}$ The partbook includes EC 14 as well, so cannot have been bound before 1558; the binder was presumably reflecting a customary change of year at Easter or Lady Day. That would mean that the voices of EC $10-11^{\delta}$ united in this binding were printed no later than the first three months or so of 1558, but nothing is presently known to confirm whether Susato reprinted EC 1214 to complete this fourth edition of the series. At present we know of no editions of any of his collections printed in 1559. Of the surviving exemplars of the motet collections, only a single reprint of Laet's 1556 Lassus collection - the 1560 EC 15 - is known to have been printed after 1559. Overall, the number of reprints postdating EC $12^{\gamma}$ again confirms that probably four editions in total existed originally, despite the manner in which the editions have survived. ${ }^{40}$ Certainly, so much has been lost that it would be unwise to doubt the original existence of editions presumed printed or reprinted (Table 7.3 gives a summary of the probable editions). Besides the total loss of EC 13, significant portions of other editions survive in nothing more than a single sheet. The fact that the production of the second edition apparently followed very soon after the first suggests that Susato had hit something of a publisher's jackpot, and probably made the most of the commercial opportunity.

\section{The chanson collections}

Susato's editions of chanson collections are less complicated than the EC motet books, and the outline of their production comparatively easy to discern. There were three series of all but the octavo Fleur series, which survives so incompletely that little can be deduced, other than the existence of two editions of the first two books. ${ }^{41}$ (Only Fleur 5 survives intact.) Those exemplars thought to represent the final printing of the quarto collections (all in A-Wn) share characteristics with the one book of this group that was redated, TS 12 of 1558. It is entirely plausible therefore that the others were printed at around the same time, perhaps beginning in 1557. The principal remaining doubt is the dating of the intermediate reprint (shown as $\beta$ ). It has been posited that this second edition (of TS 26, 1-6 \& 8 and TS Susato), possibly representing the remains of a more complete reissue of prior books, was reprinted in 1545-1546, and that, as with the EC motet collections, Susato sought to take advantage of a meeting of the Order of the Golden Fleece, this time held at Utrecht in January $1546 .{ }^{42}$ But here too, typographical features of the books point to a different chronology.

Susato made several additions to his typographical material after completing his first run of chanson books with TS 10 in August 1545. One is a ' $v$ ' sort in English italic first seen later in 1545 (in Missae 2). The second, his Basel italic fount, a larger text type whose first dated use is from August 1546 (in Missae 1). After using English italic for underlaid text in Missae 2, Susato evidently decided that it was too small for this use in the upright format of these books, and replaced it. It is unlikely therefore that any book printed with this new fount can have been printed earlier than $1546 .{ }^{43}$ Once Susato had obtained this fount, he used it extensively in all his editions of 1546-1547. He also used it for the indexes to three of the four volumes of Sacrae cantiones. ${ }^{44}$ The folio numbers given in these indexes feature a Roman ' $\mathrm{v}$ ' in the new italic fount. This was replaced by an italic sort in TS 11, printed in October 1549. That new sort can be traced through TS 12-13 of 1550 to MB 1 of 1551 . Susato, however, reverted to his original Roman form in $M B 2$ of the same year, possibly because the italic letter did not always register well.

Much of the title page and index of TS $26^{\beta}$ is set in Basel italic, with the upright form of ' $\mathrm{v}$ ' as in the editions of $1546-7$ and post $M B 1$, while TS $1^{\beta}$ displays the interim italic form. 
Both include the ' $\mathrm{v}$ ' sort in English italic, seen before only in Missae 2. TS $26^{\beta}$ must postdate the 1545 Missae 2, not only because it includes the Basel italic, but also on the basis of a split in the ornamental initial C (see Figure 7.6) which occurred during the printing of Missae 2. Because of the presence of the interim ' $\mathrm{v}^{\prime}$ sort, it seems improbable that TS $1^{\beta}$ could have been printed before Sacrae cantiones 4 of 1547; more likely, it was printed in 1549-1551. The circumstances surrounding the production of Susato's TS 11 suggest that both TS $26^{\beta}$ and TS $1^{\beta}$ were actually printed in late 1549 .

As far as it is known, Susato's press lay idle for some two and a half years following the printing of Sacrae cantiones 4 in March 1547. The lack of any noticeable wear on his ornamental initials between 1547 and 1549, and the lack of any other evidence, argues against the possibility that Susato filled this hiatus by issuing reprints. ${ }^{45}$ At present it is not known whether he had fulfilled his printing and publishing ambitions after issuing sets of collections in the three main musical genres - chansons, masses and motets - or whether other factors led him to suspend activity. There are signs that the printing of TS 11 in October 1549 was not a long-planned resumption of printing, but a response to relatively immediate financial pressures, even if Susato was comparatively well off. For a printer
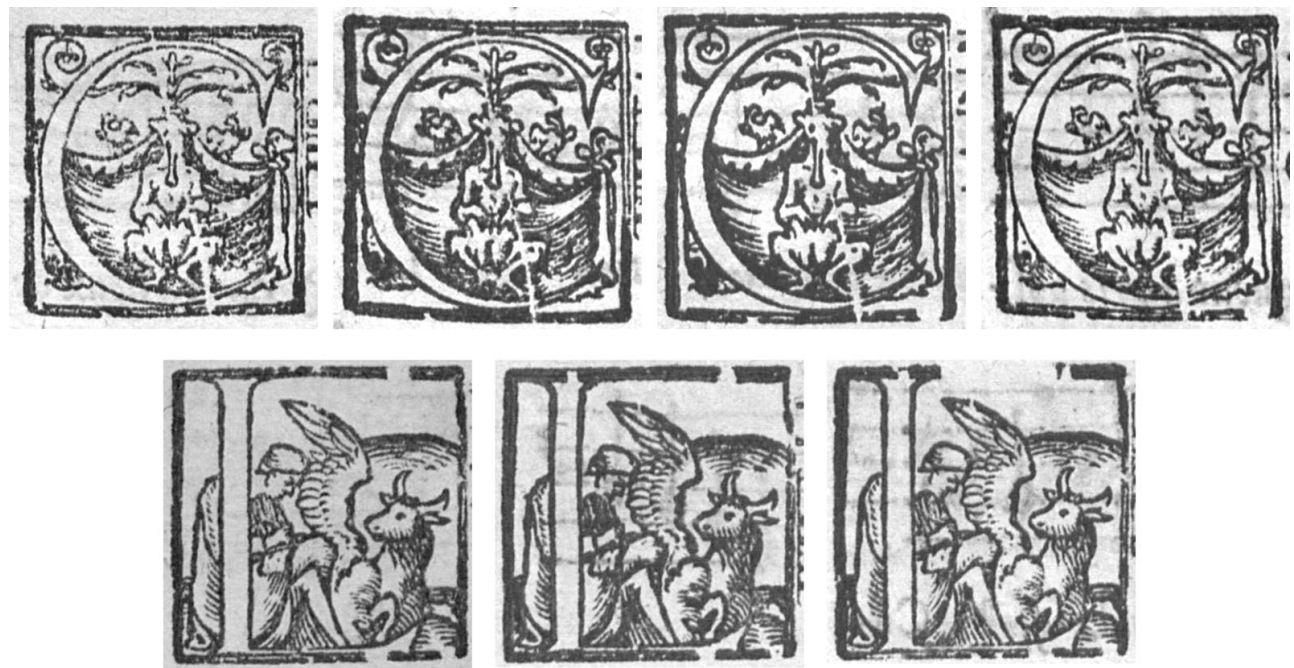

Figure 7.6 Wear on ornamental initials.

Source: Munich, Bayerische Staatsbibliothek, 4 Mus.pr. 201.

Ai. TS 11: L'unziesme livre contenant vingt \& neuf chansons amoureuses à quatre parties (Antwerp: Susato, 1549), tenor, B3'.

Aii. TS $2^{\beta}$ : Le second livre des chansons à quatre parties (Antwerp: Susato, '1544' [actually c. 1553]), superius, $\mathrm{B} 3^{\mathrm{r}}$.

Aiii. TS 2' Le second livre des chansons à quatre parties (Antwerp: Susato, '1544' [actually c. 1553]), bassus, B3r. Aiv. TS $4^{\beta}$ : Le quatriesme livre des chansons à quatre parties (Antwerp: Susato, '1544' [actually c. 1555]), superius, $B 1^{\mathrm{r}}$.

Bi. TS 11: L'unziesme livre contenant vingt \& neuf Chansons amoureuses à quatre parties (Antwerp: Susato, 1549), superius, $A 4^{\mathrm{v}}$.

Bii. TS $2^{\beta}$ : Le second livre des chansons à quatre parties (Antwerp: Susato, '1544' [actually c. 1553]), superius, $\mathrm{B} 4^{\mathrm{v}}$.

Biii. TS $4^{\beta}$ : Le quatriesme livre des chansons à quatre parties (Antwerp: Susato, '1544' [actually c. 1555], contratenor, $\mathrm{C} 4^{\mathrm{v}}$. 
such as Susato, with no steady trade in other kinds of books, the practicalities of supplies, labour, financing and distribution would mean that printing two or more collections over a relatively short period would generally be more cost-effective than printing individual items evenly spread over time. Indeed, Susato's earlier output seems to reflect this pattern. It may be doubted that TS 11 was atypical in this respect. However, the small number of editions he printed between TS 11 and the series of Musyck boexken (1551) suggest he had built up only a limited amount of new repertory. Reprints may well have helped to pad out his production schedule, while his purchase of a new sort was probably associated with a general resumption of printing.

On 11 September 1549, Philip of Spain and Charles V, accompanied by the Queens Regent and Eleanor of France, made a Joyous Entry into Antwerp. Philip was heartily disliked by the people. During the days of ceremony that followed the Entry, the town band fell foul of the Antwerp authorities, though it is unclear whether or not this was directly connected with Philip's presence. Susato and four colleagues were sacked, and paid off on 13 September; only one was later reinstated. ${ }^{46}$ In his privilege application for TS 11, Susato wrote that he had begun preparing the book in September, that is, around the time he lost his position in the town band. However, the privilege was granted only on 21 November, after Benedictus Appenzeller had examined and approved the collection just the previous day. Appenzeller's approval was based, as was normal, on a manuscript copy of the texts; it gives no reason to suppose that the authorities knew the work had already been printed. Yet Susato had gone ahead before his octroi (licence) had been granted, producing the work in October. There was no acknowledged patron for this collection, and Susato therefore appears to have taken a large financial risk, possibly even jeopardising his general privilege by acting before the work was approved for printing. The sequence of events suggests a degree of urgency on his part to secure an alternative income; likewise, the delay taken to approve the collection looks like a deliberate mark of official displeasure at his earlier offence, and an implicit warning to conduct himself better in future. ${ }^{47}$ Even so, Susato requested and received protection for six years, instead of the three that he had received for his earlier books (where the period is known), again suggesting that financial considerations were much to the fore. One could also read into the choice of repertory for TS 11 an attempt to mend fences with the authorities, who were as alert to the value of positive propaganda as they were to the dangers of heterodox beliefs. The title page specifically singles out Crecquillon, Charles V's most favoured court composer and Clemens, also within the wider court circle. Moreover, Crecquillon and the other members of the peripatetic Imperial chapel would have been present in Antwerp when Susato was preparing this publication; this would have given Susato ready access to material, had he need of it. ${ }^{48}$

The Emperor's military triumphs formed a prominent iconographical theme of the Antwerp Entry. ${ }^{49}$ TS 26 contains an extended verse dedication to the Queen Regent and with a woodcut depicting her deigning to accept the book. It also contains a canon by Susato, whose solution requires the singer to know the precise date and time of Charles V's return to Brussels after his great victory at Tunis in $1535 .{ }^{50} \mathrm{Had}$ Susato been forced by necessity to restart printing, as seems likely, he was probably looking for ways to restore his reputation through a display of loyalty; in the context of the Entry, a reprint of TS 26 would have been fitting. Alternatively, he could have chosen it to print as something uncontentious while he prepared TS 11. Since the occurrence of the new English italic ' $v^{\prime}$ sort in TS 11 and TS $1^{\beta}$ suggests that they were printed after TS $26^{\beta}$, it is likely that TS $26^{\beta}$ was printed in September or October 1549. The typographical evidence is not sufficiently clear to determine whether TS $1^{\beta}$ was printed earlier or later than TS 11, but the apparent pressures on Susato suggest that 
TS $1^{\beta}$ was printed in late 1549 or possibly early 1550. TS Susato ${ }^{\beta}$ (tenor partbook in GB-Lbl) can for similar reasons be placed in the same period. ${ }^{51}$ Susato's limited dated output of just two books in 1550 does imply that he had managed to recover his position by that time, or that he was constrained by the difficult economic conditions of that year.

Susato apparently reprinted his chanson books in order. Wear or damage to ornamental woodblock initials shows that TS $2^{\beta}$ and those books that followed must have been printed later than 1549, after TS $26^{\beta}{ }^{\beta}$ TS $1^{\beta}$ and TS Susato ${ }^{\beta}$ (see Figure 7.6). The break in the right side of the lower frame of the woodblock for the majuscule C occurred after TS 11 and 13 had been printed - this initial does not appear in TS 12 -during the production of TS $2^{\beta}$. In the first two voices (superius and tenor) it is undamaged, but in the other two voices the deterioration is clearly visible. This damage, along with a further addition to Susato's text founts (described below), provides a firm terminus a quo for TS $2-3^{\beta}$. This terminus also applies to subsequent books, because the comparison of a second initial, the L block, confirms that TS $4^{\beta}$ and the remainder were printed later still. ${ }^{52}$

The addition to Susato's text founts arose from the introduction of his second and smaller music type in $M B 1$ of 1551 . His existing italic text founts were both too large to partner it; for this he needed a third: his pica italic. This has identified with a fount used by Steelsius of Antwerp, which also appeared first in 1551. Although this identification is questionable, it still seems doubtful that Susato would have purchased his fount before $1550-1551 .^{53}$ While Susato used his pica italic for the first time in the dedication of TS 13 from 1550 (if this date is accurate), and not in $M B 1$, he certainly had not employed it in any previous publication dated with a true year of printing. ${ }^{54}$ Moreover, as it contains a ' $\mathrm{w}$ ' sort, he clearly intended to use it for the Musyck boexken series, in which it would be required to set Dutch texts.

This new pica italic fount appears extensively in both TS 2 and $3^{\beta}$. TS $2^{\beta}$ uses it on the title page, for the entire index, and for headers throughout, while a large portion of the combined title page and index of TS $3^{\beta}$ is set in this fount (see Figure 7.7). The presence of the pica italic fount confirms the evidence provided by observations of wear to the woodcuts, to support the conclusion that these two reprints were produced no earlier than 1550-1551. A further detail from two of the EC motet series allows us to narrow the range of possible production dates even further. In the EC series, Susato confined himself to pica and/or Basel italics (except for title pages). He used English italic only on two occasions: for the signatures in the first edition of EC 1 and 2. EC 1 varies between the expected pica italic and English italic, while EC 2 has only a single instance of English italic, though transferred between voices. ${ }^{55}$ In EC 1, this cannot have been the result of foul case (the presence of sorts from another fount in the case, resulting from carelessness in replacing the type after printing); the consistent make-up of the respective signatures from eight different compartments of the case makes this impossible. A similar mixture of these two founts is also found in the signatures of TS $2^{\beta}$. We can infer that the case of English italic was being used for TS $2^{\beta}$ at the same time as EC 1 was being typeset. It is therefore probable that the editions TS $2-3^{\beta}$ date from early 1553, when Susato was beginning production of the EC series. In addition to the cumulative wear on ornamental initials, the use of Susato's later house style (Basel italics for headers) in TS $4-6$ and $8^{\beta}$ places them later still. ${ }^{56}$ However, there is no sign of the cracking evident in the large woodblock initial T found in the tenor partbook of Susato's Lassus collection, TS 14 of 1555 (see Figure 7.8). Given that Susato was concentrating on producing motet books through 1553 and much of 1554 (if not the entire year), we may suppose that TS $4-6$ and $8^{\beta}$ were reprinted in 1555 , prior to TS $14 .{ }^{57}$ 


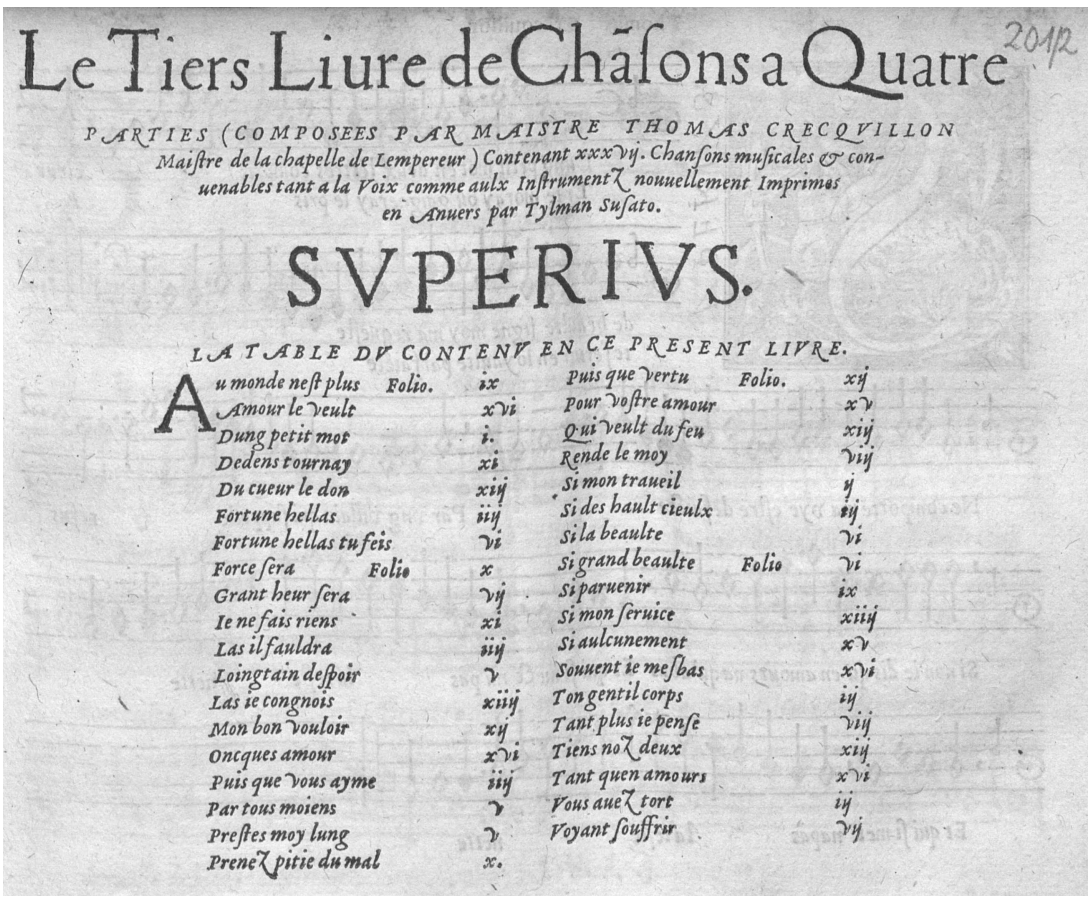

Figure 7.7 Title page of TS $3^{\beta}$ showing the extensive use of pica italic: Le tiers livre de chansons a quatre parties (Antwerp: Susato, ' $1544^{\prime}$ [actually c. 1553]), superius, A1 .

Source: Munich, Bayerische Staatsbibliothek, 4 Mus.pr. 201.
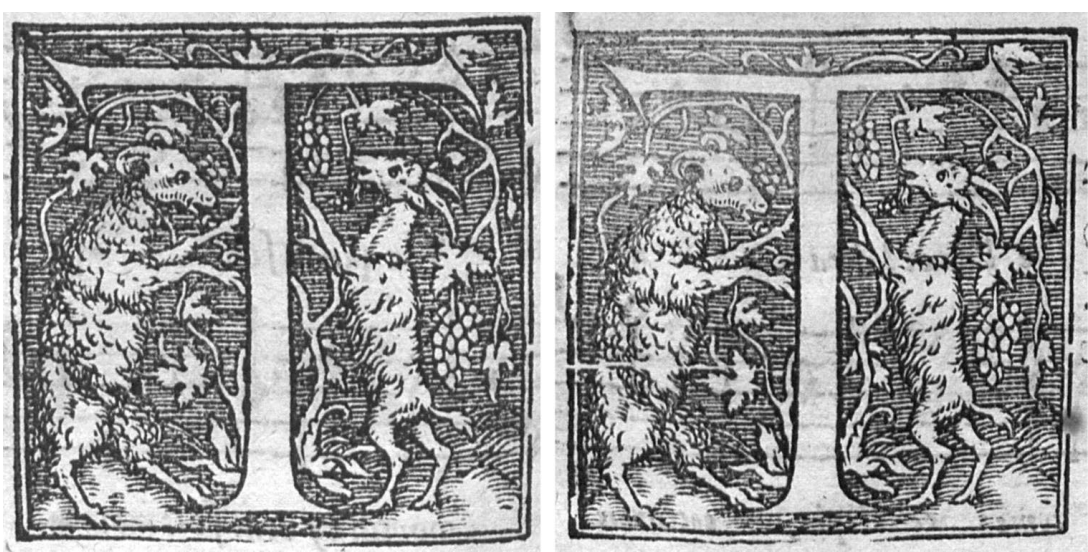

Figure 7.8 Comparison of ornamental initials between TS $4^{\beta}$ and TS 14 of 1555.

(a) TS 4: Le quatriesme liore des chansons à quatre parties (Antwerp: Susato, '1544' [actually c. 1555]), tenor, $\mathrm{A} 2^{\mathrm{r}}$.

Source: Munich, Bayerische Staatsbibliothek, 4 Mus.pr. 201.

(b) TS 14: Le quatoirsiesme liore à quatre parties (Antwerp: Susato, 1555), tenor, $\mathrm{A} 2^{\mathrm{r}}$.

Source: Munich, Bayerische Staatsbibliothek, 4 Mus.pr. 135. 


\section{Summary}

This reconsideration of Susato's motet and chanson books and their reprints shows that he was less active as a printer in the 1540s than has previously been thought, but much more productive in the 1550s. The revised dates of production I propose here may still represent an under-estimate of his later activities. The pattern of production of EC collections in 1557, for instance, suggests that he produced more reprints than can currently be identified. Moreover, he may have produced a second edition of the first four books of Souterliedekens at some point. ${ }^{58}$ It is unclear whether Susato's earlier, more limited output reflects the lack of a developed market or distribution network, or his own wish to balance printing with his other activities. Perhaps surprisingly, Susato did not take great assemblies as major marketing opportunities for series of newly issued reprints. It may be that his pace of production was too slow, and the consequent accumulation of invested capital and debt too great to make this an attractive proposition. In any case, the evident success of the EC motets would have made reliance on special occasions redundant; and by then Susato obviously had the means of effective dissemination regardless.

The later years of Susato's printing office have at times been characterised as a period of decline in which he produced comparatively few new works. The dating of a complete edition of the EC books to 1553 means that he produced even fewer than previously thought. However, his emphasis on reprints highlights a necessary distinction, which may be applied more widely: from a modern perspective, a paucity of new works may make a printer's output less immediately interesting, but that is not necessarily to be equated with decline. Repeat editions had decided advantages for the printer: he had no need to source fresh repertory or apply for a new privilege; a tested market; and no requirement for specialised editorial input. That made a reprint copied from a previous edition quicker and cheaper to produce, while the use of hidden editions allowed the printer to chisel his backers. ${ }^{59}$ Apparent decline can actually signal the continuing marketability of the original product with greater profit margins; in other words, commercial success.

More narrowly, the existence of redated and hidden editions - the choice of model in the latter case possibly determined simply by the books Susato had readily to hand - together with the presence of a mixture of sheets and editions within individual bindings, provides a frame in which to reconsider variants and problems of attribution, and in some cases explain them.

Finally, Susato's success gave a commercially viable example for others to follow. It can be argued that Phalèse in particular was an imitator, rather than an independent rival. So by that very success, Susato indirectly enriched the common legacy well beyond his own specific contribution.

\section{Appendix 7.1}

\section{Susato's music and text founts}

1. Music type 1: from 1543 onwards. Used for chanson books except for octavo Fleur 1-6; Missae 1-3 and SC 1-4.

2. Text type 1: English italic, mainly used with music type 1 for underlaid text in chanson books except for Fleur 1-6, prior to reprints (ii) (see Appendix 7.2), plus Missae 2 (1545). 


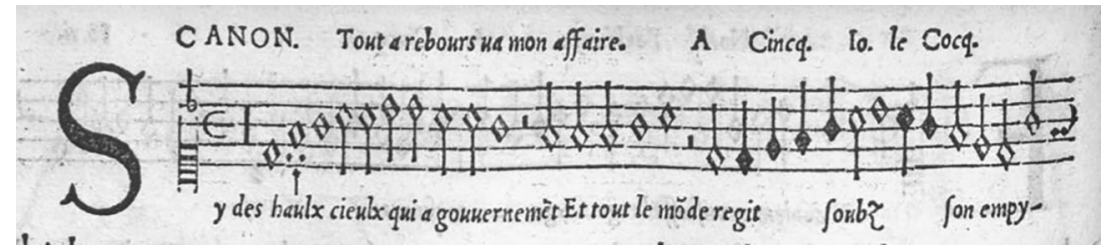

3. Music type 2: from 1551 for MB 1-11, Fleur 1-6, and EC 1-15.

4. Text type 2: pica italic. First dated use 1550, TS 13; mainly used for underlaid text with music type 2; also used with music type 1 in chanson reprints (ii) and TS 14.

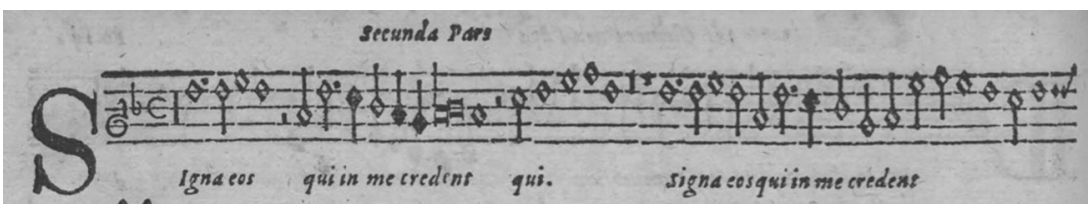

5. Text type 3: Basel italic. First dated use August 1546, Missae 1; used for underlaid text only for Missae 1 and 3, and SC 1-4. Otherwise Text type 3 is used for title pages, some indexes, headers etc.

\begin{tabular}{lll}
\hline Gaudetu baptifta & $x v i$ & Ioannes Lupi \\
In te domine fperaui & iij & Clemens non Papa \\
In bonore matris & $v i i j$ & Euftacius Barbion \\
In bonore beatiffime & $x i j$ & Clemens non Papa \\
In illotempore & $x v$ & Brumen \\
Memento falutis & $x i$ & Thomas Cricquillon
\end{tabular}

\section{Changing/new sorts within founts}

1. English italic ' $\mathbf{v}$ '

a) 1543-1545, TS 10:

\section{vous voye}

b) 1545, Missae 1; chansons 1549, TS 11 onwards:

\section{vous voye}

2. Basel italic ' $v$ ' and ' $w$ '

a) 1546-1547 and $1551 M B 2$ to 1556:

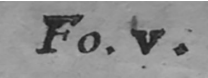

b) from October 1549, TS 11, to 1551, MB 1

\section{$v i$}

d) 'w' from 1556 SL 1 (no earlier form):

c) 1556, SL 1 onwards: 


\section{Appendix 7.2 Susato's publications, other than Liber primus- XIIII ecclesiasticarum cantionum}

Estimated dates of undated or hidden editions are given in square brackets; dated editions without brackets.

\begin{tabular}{|c|c|c|c|c|}
\hline Year & $\begin{array}{l}\text { RISM } \\
\text { siglum }\end{array}$ & Collection & Reprints (i) & Reprints (ii) \\
\hline 1543 & {$[1543]^{15}$} & Vingt et six chancons [sic] (TS 26) & [1549] & \\
\hline 1543 Nov. & $1543^{16}$ & $\begin{array}{l}\text { Premier livre des chancons [sic] a } \\
\text { quatre (TS } 1 \text { etc.) }\end{array}$ & [1549-1550] & [1558] \\
\hline 1544 & S7238 & $\begin{array}{l}\text { Premier livre des chansons a troix } \\
\text { (Susato) (TS Susato) }\end{array}$ & [1549-1550] & [1558] \\
\hline 1544 Sept. & $1544^{10}$ & Le second livre $\ldots$ a quatre & [1553] & [1558] \\
\hline 1544 & {$[1544]^{11}$} & $\begin{array}{l}\text { Le tiers livre } \ldots \text { a quatre } \\
\text { (Crecquillon) }\end{array}$ & [1553] & [1558] \\
\hline 1544 Oct. & $1544^{12}$ & Le quatriesme livre $\ldots$ a quatre & [1555] & [1558] \\
\hline 1544 Dec. & $1544^{13}$ & $\begin{array}{l}\text { Le cincquiesme livre ... a cincq et } \\
\text { a six }\end{array}$ & {$[1555]$} & [1558] \\
\hline $\begin{array}{l}1544 \text { Dec./ } \\
1545 \text { Jan. }\end{array}$ & $1545^{14}$ & Le sixesme livre $\ldots$ a cincq et a six & [1555] & [1558] \\
\hline 1545 & $1545^{15}$ & Le septiesme livre $\ldots$ a cincq et six & & [1558] \\
\hline 1545 May & $1545^{16}$ & Le huitiesme livre $\ldots$ a quatre & [1555] & [1558] \\
\hline 1545 July & M270 & $\begin{array}{l}\text { Le neufiesme livre ... a quatre } \\
\text { (Manchicourt) }\end{array}$ & & [1558] \\
\hline 1545 Aug. & $1544^{17}$ & Le dixiesme livre & & [1558] \\
\hline 1545 & $1545^{1}$ & $\begin{array}{l}\text { Liber secundus missarum (Missae } \\
2 \text { etc.) }\end{array}$ & & \\
\hline 1546 Aug. & $\begin{array}{l}1546^{3} \\
1546^{4}\end{array}$ & $\begin{array}{l}\text { Liber primus missarum } \\
\text { Liber tertius missarum }\end{array}$ & & \\
\hline 1546 & $1546^{7}$ & $\begin{array}{l}\text { Liber secundus sacrarum } \\
\text { cantionum quinque vocum }{ }^{1} \\
\text { (Sacrae cantiones / SC } 2 \text { etc.) }\end{array}$ & & \\
\hline 1546 & $1546^{6}$ & $\begin{array}{l}\text { Liber primus sacrarum cantionum } \\
\text { quinque vocum }\end{array}$ & & \\
\hline 1547 & $1547^{5}$ & $\begin{array}{l}\text { Liber tertius sacrarum cantionum } \\
\text { quatuor vocum }\end{array}$ & & \\
\hline 1547 March & $1547^{6}$ & $\begin{array}{l}\text { Liber quartus sacrarum cantionum } \\
\text { quatuor vocum }\end{array}$ & & \\
\hline 1549 Oct. & $1549^{29}$ & L'unziesme livre ... a quatre & & [1558] \\
\hline 1550 & $1550^{13}$ & $\begin{array}{l}\text { Le douziesme livre } \ldots \text { a cincq } \\
\mathrm{R}=1558^{9}\end{array}$ & & 1558 \\
\hline 1550 & $1550^{14}$ & Le treziesme livre ... a six et a huit & & \\
\hline 1551 & $1551^{18}$ & $\begin{array}{l}\text { Het erste musyck boexken mit } \\
\text { vier partyen }(M B 1 \text { etc. })\end{array}$ & & \\
\hline 1551 & $1551^{19}$ & $\begin{array}{l}\text { Het tveeste musyck boexken mit } \\
\text { vier }\end{array}$ & & \\
\hline 1551 & S7238a & Het derde musyck boexken & & \\
\hline [1552] & {$[1552]^{7}$} & $\begin{array}{l}\text { La fleur de chansons et premier } \\
\text { livre a quatre (Fleur } 1 \text { etc.) }\end{array}$ & $?$ & \\
\hline [1552] & {$[1552]^{8}$} & La fleur ... second livre a quatre & ? & \\
\hline [1552] & S7239 & Tiers livre $\ldots$ a deux ou a troix ${ }^{2}$ & & \\
\hline [1552] & {$[1552]^{9}$} & $\begin{array}{l}\text { La fleur ... quatriesme livre a } \\
\text { quatre }\end{array}$ & & \\
\hline
\end{tabular}




\begin{tabular}{|c|c|c|c|c|}
\hline Year & $\begin{array}{l}\text { RISM } \\
\text { siglum }\end{array}$ & Collection & Reprints (i) & Reprints (ii) \\
\hline 1552 May & $1552^{10}$ & $\begin{array}{l}\text { La fleur ... cincquiesme livre a } \\
\text { troix }\end{array}$ & & \\
\hline 1552 July & $1552^{11}$ & La fleur ... sixiesme livre a troix & & \\
\hline 1555 & $1555^{29 / 19}$ & $\begin{array}{l}\text { Le quatoirsiesme livre ... a } \\
\text { quatre/Il primo libro (Lassus) } \\
\mathrm{R}=1560^{4} \text { (in TS } 14 \text { form) }\end{array}$ & [1557] & 1560 \\
\hline 1556 & $\mathrm{C} 2708$ & $\begin{array}{l}\text { Souterliedekens I Het vierde } \\
\text { musyck boexken (Clemens) (SL } 1 / \\
\text { MB } 4 \text { etc.) }\end{array}$ & $? ?^{3}$ & \\
\hline 1556 & C2709 & Souterliedekens II (Clemens) & ?? & \\
\hline 1556 & $\mathrm{C} 2710$ & Souterliedekens III (Clemens) & ?? & \\
\hline 1557 & $\mathrm{C} 2711$ & Souterliedekens IIII (Clemens) & ?? & \\
\hline 1560 & L763 & $\begin{array}{l}\text { Orlando di Lassus. Liber } \\
\text { decimus quintus ecclesiasticarum } \\
\text { cantionum }\end{array}$ & & \\
\hline \multirow[t]{4}{*}{1561} & M2384 & $\begin{array}{l}\text { Souterliedekens V Het achste } \\
\text { musyck boexken (Mes) }\end{array}$ & & \\
\hline & ditto & Souterliedekens VI (Mes) & & \\
\hline & ditto & Souterliedekens VII (Mes) & & \\
\hline & ditto & Souterliedekens VIII (Mes) & & \\
\hline
\end{tabular}

1. Typographical details show that SC 2 was printed before SC 1 .

2. It is unclear whether or not this was intended as part of the Fleur series, but it is in the oblong octavo format found otherwise only in this series, and uses the same text and music founts introduced in 1550-1551.

3. See note 58 in this chapter; it is uncertain whether the series was reprinted, but it seems quite probable.

\section{Appendix 7.3 Liber primus-XIIII ecclesiasticarum cantionum}

\section{Known exemplars}

CZ-AbK: EC 1-9

D-As: EC 1-12

D-B(i): EC 8-11:

D-B(ii) formerly Bds-Tü: EC 1-12

D-Kl: EC 1-14 (Q only for 12 \& 14); https:/ / orka.bibliothek.uni-kassel.de/viewer/

D-LÜh: EC 1-11 (S \& Q)

D-Mbs: EC 1-7; https:/ /www.digitale-sammlungen.de/

E-Mn: EC 5-11 (Q); http:/ /www.bne.es/es/Catalogos/BibliotecaDigitalHispanica/Inicio/ index.html

GB-Lbl EC 1-11 (ex. S: 6, 10-11); http:/ / explore.bl.uk/

GB-En EC 1-8 (B)

H-BA: EC 7 \& 10 (STQ)

NL-DH: EC 4-11 (A+SB for 5-7)

S-Sk: EC 5-11 (S)

S-Uu: EC 1-14 (ex. C); http:/ /info.alvin-portal.org/

S-Vx: EC 1-11 (ex S)

Us-Lu: EC 1-8

US-NYp: EC 1-11

Privately owned: EC 1-8 (T); sold at auction by Sotheby's in 2011, present whereabouts unknown. To judge from information kindly supplied by Sotheby's, it may be a companion partbook to GB-En. 


\section{Brief distinguishing markers}

A(i): quatuor / quinque uocum; Vulgo Moteta uocant ... cōpofitarum; M.D.LIII; Cum gratia $\mathcal{E}$ privilegio || Cefareæ Maieftatis || [Hedera]; headers in pica italic

A(ii): as A(i) with privilege: Cum gratia \& privilegio || Cefarex Maieftatis || De Lange. || [Hedera]; headers in Basel italic from EC 6 onwards

A(iii): as A(ii) with year: M.D.LIIII. All headers in Basel italic.

B(i): quinque uocum; Vulgo Moteta uocant ... compofitarum; M.D.LV; Cum gratia \& privilegio Cefarex || Maie. Sub figne de Lange | | [Hedera] (EC 10-11 only)

B(ii): quatuor / quinque vocum; Vulgo Moteta vocant ... compofitarum; M.D.LIII or M.D.LIIII for hidden eds.; (privilege follows model in hidden ed.). EC $9^{\delta}$ has Veteri for Veteri of all earlier editions.

C: quinque vocum; Vulgo Moteta vocant ... Compofitarum. all in Basel italic.

\section{Exemplars by edition for those seen or for which information is available}

Sheets belonging to earlier editions than the remainder are shown thus: Voice [sig.]; the later reference is to be read as excluding any such sheets.

\begin{tabular}{|c|c|c|c|c|c|c|}
\hline & $\begin{array}{l}\text { Ed. } \alpha \\
\text { A(i) }\end{array}$ & $\begin{array}{l}\text { Ed. } \beta \\
\text { A(ii) }\end{array}$ & $\begin{array}{l}\text { Ed. } \gamma \text { (part) } \\
\text { A(iii) }\end{array}$ & $\begin{array}{l}\text { Ed. } \gamma \text { (part) } \\
\text { B(i) \& (ii) }\end{array}$ & $\begin{array}{l}\text { Ed. } \delta \text { (part) } \\
\text { B(ii) }\end{array}$ & $\begin{array}{l}\text { Ed. } \delta \text { (part) } \\
\text { C }\end{array}$ \\
\hline$E C 1$ & $\begin{array}{l}\text { D-As D-K1 } \\
\text { D-LÜh D-Mbs } \\
\text { GB-En S-Vx } \\
\text { Us-Lu US-NYp }\end{array}$ & & & & $\begin{array}{l}\text { D-B(ii) GB- } \\
\text { Lbl S-Uu }\end{array}$ & \\
\hline EC 2 & $\begin{array}{l}\text { D-As D-K1 } \\
\text { D-LÜh D-Mbs } \\
\text { GB-Lbl GB-En } \\
\text { S-Vx Us-Lu } \\
\text { US-NYp }\end{array}$ & & & & D-B(ii) S-Uu & \\
\hline EC 3 & $\begin{array}{l}\text { D-As D-Kl } \\
\text { D-LÜh D-Mbs } \\
\text { GB-En S-Uu } \\
\text { S-Vx Us-Lu } \\
\text { US-NYp }\end{array}$ & & & & $\begin{array}{l}\text { D-B(ii) } \\
\text { GB-Lbl }\end{array}$ & \\
\hline EC 4 & see note 2 & & $\begin{array}{l}\text { D-As D-Kl } \\
\text { D-LÜh } \\
\text { D-Mbs GB- } \\
\text { Lbl }^{3} \text { GB-En } \\
\text { S-Vx Us-Lu } \\
\text { US-NYp }\end{array}$ & & $\begin{array}{l}\text { D-B(ii) } \\
\text { S-Uu; B[e] } \\
\text { GB-B1 }{ }^{3}\end{array}$ & \\
\hline EC 5 & $\begin{array}{l}\text { C[a] \& All[c-d]: } \\
\text { D-As D-Kl(xQ) } \\
\text { D-Mbs E-Mn } \\
\text { S-Sk S-Vx Us-Lu } \\
\text { US-NYp }\end{array}$ & $\begin{array}{l}\text { D-As D-Kl(xQ) } \\
\text { D-LÜh D-Mbs } \\
\text { E-Mn GB-En } \\
\text { S-Sk S-Vx } \\
\text { Us-Lu US-NYp }\end{array}$ & & & $\begin{array}{l}\text { D-B(ii) } \\
\text { D-Kl(Q) } \\
\text { GB-Lbl } \\
\text { S-Uu }\end{array}$ & \\
\hline EC 6 & $\begin{array}{l}\text { ST[c-d] C[a]: } \\
\text { D-As D-Kl } \\
\text { D-LÜh D-Mbs } \\
\text { GB-Lbl S-Uu } \\
\text { S-Vx US-NYp }\end{array}$ & $\begin{array}{l}\text { D-As D-Kl(xQ) } \\
\text { D-LÜh D-Mbs } \\
\text { E-Mn GB-Lbl } \\
\text { GB-En S-Sk } \\
\text { S-Uu S-Vx } \\
\text { US-NYp }\end{array}$ & & & $\begin{array}{l}\text { D-B(ii) } \\
\text { D-Kl(Q) }\end{array}$ & \\
\hline
\end{tabular}




\begin{tabular}{|c|c|c|c|c|c|c|}
\hline & $\begin{array}{l}\text { Ed. } \alpha \\
\text { A(i) }\end{array}$ & $\begin{array}{l}\text { Ed. } \beta \\
\text { A(ii) }\end{array}$ & $\begin{array}{l}\text { Ed. } \gamma \text { (part) } \\
\text { A(iii) }\end{array}$ & $\begin{array}{l}\text { Ed. } \gamma \text { (part) } \\
\text { B(i) \& (ii) }\end{array}$ & $\begin{array}{l}\text { Ed. } \delta \text { (part) } \\
\text { B(ii) }\end{array}$ & $\begin{array}{l}\text { Ed. } \delta \text { (part) } \\
\text { C }\end{array}$ \\
\hline$E C 7$ & $\begin{array}{l}\text { C[a]: D-As D-K1 } \\
\text { D-Mbs, GB-Lbl } \\
\text { S-Vx Us-Lu } \\
\text { US-NYp }\end{array}$ & $\begin{array}{l}\text { D-As D-Kl(xQ) } \\
\text { D-LÜh D-Mbs } \\
\text { E-Mn GB-Lbl } \\
\text { GB-En S-Sk } \\
\text { S-Uu S-Vx } \\
\text { Us-Lu US-NYp }\end{array}$ & & & $\begin{array}{l}\text { D-B(ii) } \\
\text { D-Kl(Q) }\end{array}$ & \\
\hline EC 8 & $\begin{array}{l}\text { C[a]: D-As D-Kl } \\
\text { D-Mbs GB-Lbl } \\
\text { S-Vx Us-Lu }\end{array}$ & $\begin{array}{l}\text { D-As D-Kl(xQ) } \\
\text { D-LÜh D-Mbs } \\
\text { E-Mn GB-Lbl } \\
\text { GB-En S-Sk } \\
\text { S-Uu S-Vx } \\
\text { Us-Lu }\end{array}$ & & & $\begin{array}{l}\text { D-B(ii) } \\
\text { D-Kl(Q) }\end{array}$ & \\
\hline EC 9 & $\begin{array}{l}\text { C[a]: D-As D-K1 } \\
\text { GB-Lbl S-Vx } \\
\text { US-NYp }\end{array}$ & & $\begin{array}{l}\text { D-As } \\
\text { D-Kl(xQ) } \\
\text { D-LÜh } \\
\text { E-Mn, GB- } \\
\text { Lbl, S-Sk } \\
\text { S-Uu S-Vx } \\
\text { US-NYp }\end{array}$ & & $\begin{array}{l}\text { D-B(ii) } \\
\text { D-Kl(Q) }\end{array}$ & \\
\hline EC 10 & $\begin{array}{l}\text { C[a]: D-K1 } \\
\text { GB-Lbl S-Vx } \\
\text { US-NYp }\end{array}$ & & & $\begin{array}{l}\text { D-As } \\
\text { D-Kl(xQ) } \\
\text { D-LÜh E-Mn } \\
\text { GB-Lbl S-Sk } \\
\text { S-Uu S-Vx } \\
\text { US-NYp }\end{array}$ & & $\begin{array}{l}\text { D-B(ii) } \\
\text { D-Kl(Q) }\end{array}$ \\
\hline EC 11 & & & & $\begin{array}{l}\text { D-As } \\
\text { D-Kl(xQ) } \\
\text { D-LÜh E-Mn } \\
\text { GB-Lbl S-Sk } \\
\text { S-Uu S-Vx } \\
\text { US-NYp }\end{array}$ & & $\begin{array}{l}\text { D-B(ii) } \\
\text { D-Kl(Q) }\end{array}$ \\
\hline EC 12 & $\begin{array}{l}\text { C[a]: D-As } \\
\text { D-B(ii) }\end{array}$ & $\begin{array}{l}\text { ? S[c]: D-As } \\
\text { D-B(ii) S-Uu; }\end{array}$ & & $\begin{array}{l}\text { D-As D-B(ii) } \\
\text { D-K1(Q) } \\
\text { S-Uu }\end{array}$ & & \\
\hline EC 14 & $\begin{array}{l}\text { Q[a]: D-B(ii) } \\
\text { D-Kl S-Uu }\end{array}$ & & & D-B(ii) S-Uu & & \\
\hline
\end{tabular}

1 RISM entries for EC 4 at US-R \& US-Wc are in error.

2 RISM notes exemplar(s?) of EC 4 with dates of 1553 in S \& C. These are not in the copies seen. Nevertheless, early bibliographies give convincing evidence of a 1553 first edition. See for instance Becker, 'Goudimel et son oeuvre', 351. 3 See text regarding sheets in this exemplar and EC 7.

\section{Acknowledgements}

I am especially grateful to those libraries holding Susato's publications who have made copies available, provided access and answered queries.

\section{Notes}

1 RISM B/I $1542^{7}$ and RISM A/I A1291. See Vissenaecken's address to the reader (in the tenor partbook), and the privilege for Loys and Buys, in Thompson, 'Henry Loys and Iehan de Buys', 113.

2 Of particular relevance to this study are Meissner, Antwerpener Notendrucker; Forney, 'Tielman Susato'; Forney, 'New Insights'; Forney, 'Orlando di Lasso's “Opus 1"'; Cardamone and Jackson, 
'Multiple Formes'; Dehnert, 'Libri'. It has been suggested that the 'Kamper liedboek' may have been printed in Antwerp c. 1535; see Fallows, 'The Printed Songbook at Kampen'.

3 Susato resurrected the title for his 1560 reprint of Lassus' motet collection (EC 15), first issued by Laet in 1556.

4 Meissner, Antwerpener Notendrucker, vol. 1, Section II.2; her variants list, 74, is partly inaccurate.

5 Brown, 'Review', 108-109.

6 Forney, 'New Insights', 20. The original existence of EC 13 has been flatly denied (Bernet Kempers, 'Die Sigel', 108-109) or doubted (Dehnert, 'Libri', 1). Bernet Kempers' unprovable assertion that it was omitted for superstitious reasons takes no account of the signatures, which make it clear that a thirteenth book was part of Susato's plan, and hardly squares with the fact that Susato earlier printed TS 13. This particular superstition is in any event more recent: 'Thirteen: unlucky number', A Dictionary of Superstitions, gives for its earliest literature reference the year 1893.

7 Forney, 'New Insights', 9-10.

8 See, for example, on EC 14: Bernet Kempers, 'Die Sigel'; Clemens non Papa: Omnia opera, 4/13: vii; Forney, 'Tielman Susato', 103-104. Forney's subsequent 'Lassus “Op. 1"', 42 n. 41, did recognise Meissner's points, and put forward a brief hypothesis of an 'atypical production method'. It is in some crucial respects incompatible with her later chronology quoted above.

9 Which would have made it 1554 in modern reckoning.

10 There is no published evidence, as far as I can find, to support the statement that several of the series were first printed in 1552 .

11 An estimate given by a highly experienced modern compositor suggests that it would have taken three to four hours to set the title page and index of each partbook, amounting to twelve to sixteen hours' work per five-voice collection if these elements were reset, plus additional time for proofing and corrections. Of course, this does not mean that minor elements might not be adjusted. Maintaining as much as possible of the title page between books would again result in worthwhile savings. For an example, even where much of the title pages were different, see TS 5 and 6 from 1544/5, especially the quinta \& sexta pars of each. In referring to identical title pages, I take necessary changes for voice, series number and so on as read. When other work supervened, standing type might be cannibalised, so that only parts remained for reuse.

12 No resetting will ever reproduce exactly the distribution of individual type pieces with distinctive facets, damage or wear, even if the orthography is unaltered.

13 A single sheet represents a rather higher percentage of a modestly sized set of partbooks such as Susato's, compared with one in a larger book; the cost implications of a cancel sheet would be correspondingly greater.

14 Voices were often worked in pairs, superior-tenor, contratenor-bassus, with the quinta pars taking set type from the others as convenient. Superior, rather than superius, was Susato's own designation of the voice in almost all the EC series.

15 Relevant exemplars are identified in Appendix 7.2. Several can be compared online.

16 The variations go well beyond the small portion of the page shown in Figure 7.2: in swash letters, faults on other letters and so on.

17 That is taking account of the shrinkage of the paper on drying after its initial printing.

18 In addition, the signatures in this gathering of the superior are set in pica italic, not the Basel italic of all the other voices. There are further variants; for example, the gathering opens with the secunda pars of Barbion's Girum coeli. In the superior, the text reads: 'et thronus meus in columba [sic] nubis'; that in all the other voices is 'et tronus meus in columna nubis'. The correction of 'columba' to 'columna' in the other voices also suggests that this gathering was printed earlier. While errors and variant spellings are to be found between voices in a single edition, they are likely to be significant in combination with the other distinguishing features.

19 See note 8; Bernet Kempers correctly pointed out the fact of a single edition in 1557/58.

20 In two partbooks 'Liber XIIII' has been crudely altered by hand to read 'XIII', suggesting that someone, lacking $E C$ 13, wanted to give the appearance of complete runs.

21 The CZ-AbK (Kroměřž Archiepiscopal Castle library) copy of EC 9 has been catalogued under 1553. It may therefore represent a more complete survival, but I have been unable to verify the details.

22 The British Library online catalogue (accessed 31 January 2019) identifies the errant sheet in EC 7, but is incorrect in noting that it represents a different edition to GB-Lbl EC 4. It is the relative sheet in EC 4 that is aberrant. On the original binding, see Milsom, 'The Nonsuch library', 154-155. 
23 Gathering E of EC 1 shows a marked divergence between the superior and the other three voices in both headings and some points of orthography. However, taking into account some peculiarities of the underlaid text, the initial letters and signatures, it seems likely the differences arose during the production of a single edition.

24 This supposition is strengthened by the later of these two editions' indexing Manchicourt's Ave stella matutina as Clemens' Ave maris stella (probably confused with this motet in EC 6 when reprinting).

25 Compare, for example, the D-Kl and S-Uu exemplars.

26 'Finis liber primus'; all the relevant copies seen have this altered to 'Finis libri primi', and so it was likely done in-house.

27 Again, other than in the later hidden edition.

28 Susato in EC 3 had listed composers, but the number of works meant the index had to be set in pica italic, a much more time-consuming process than using Basel italic.

29 The possible reasons for the mixture of hidden and truly dated editions within the corpus and the variation in privileges need more extensive discussion than can be accommodated here.

30 A comma within a line of type may seem a negligible difference, but in terms of practical printing and the reuse of standing type, it is far from being so.

31 Because of their apparent overlap, I have distinguished the hypothetical editions as in Table 7.3.

32 For example, the line 'Antea nvnquam excusvs' is set not in Basel italic, but in small Roman capitals; furthermore, the printer and address lines and privilege have been changed. Though the comparisons rest on rather more points, for two easily seen identifying details in what was carried across from $E C 11$ to $E C 1^{\delta}$, and then to $3^{\delta}$ and $12^{\gamma}$, see the faults on the second $C$ and first $\mathrm{A}$ in ECCLESIASTICARVM.

33 In addition, the Basel italic ' $w^{\prime}$ ' sort appears in EC 2,5 and $8^{\delta}$, as well as in EC $12^{\gamma}$.

34 The printer/address line and date are clear and indicative.

35 'quatuor vocum' is from the same type in both EC 1 and $3^{\delta}$. The change to 'quinque vocum' for $E C 12^{\gamma}$ must have come after $E C 3^{\delta}$.

36 The three lines Vulgo Moteta vocant ... are possibly identical, but certainly respaced if so.

37 See again the printer/address line and date. The distinctive spacing mentioned in the previous note is also still evident.

38 The balance of the evidence suggests that EC 13 was printed between $E C 8^{\delta}$ and $14^{\gamma}$, but in the absence of a known exemplar, this hypothesis cannot be validated.

39 The date is unclear on my reproduction. I take it from Horstmann, Katalog, 284.

40 Appendix 7.2 shows that many of the surviving exemplars of the earlier editions contain an identical mixture of aberrant sheets. One possible reason for this, in part at least, is that Susato may have been printing his second and third editions while sheets from the first were still in his warehouse or that of a significant distributor. It is easy to imagine new sheets sometimes being placed on top of the relevant pile, but at other times being more carefully put underneath any remaining sheets from earlier. Then, when sheets were collated for sale or further distribution, they would all be taken off the top, resulting in a number of exemplars with the same make-up, and sheets being used some time after they were produced.

41 I have been unable to see a copy of the F-CH partbook of Fleur 2, which might offer clues as to its dating.

42 Forney, 'Tielman Susato', 191-192, Table 11, summarises the editions for most of the exemplars then known. I base my comments on the relevant exemplars at D-Mbs and GB-Lbl. The RISM opac listings (accessed 31 January 2019) do not include copies of TS 1-3 or 8 at E-Bbc or TS Susato at B-A. Forney identified the second edition from the corrections to Susato's initially idiosyncratic index numbering of folios. His use of founts supports Forney's categorisation. On her dating of the second and third editions, see 'New Insights', 9-10, 20.

43 If Susato's Basel italic was cut specifically for him, it might help explain the prolonged gap between Missae 2 and Missae 1.

44 Sacrae cantiones 2, printed before Sacrae cantiones 1, uses Roman type for the index.

45 Idle periods, though not quite so extended, occur earlier in Susato's output. Even so, the press might not actually have been unproductive; presses could be rented out to other printers, and printers might take on subcontract work.

46 Goovaerts, Histoire, 31. 
47 The documents are in Meissner, Antwerpener Notendrucker, 2: 159; Forney, 'Tielman Susato', 252-258. The relevant ordinance forbade any printing whatsoever without a general privilege; then, before being printed, each individual book required the grant of a specific octroi, which depended on official approvals - both ecclesiastical and lay - of its contents; music was not exempt in any way, nor was retrospective approval countenanced. Sale and distribution could only take place once a printed copy had been lodged with, and checked by, the authorities as conforming to the permissions: Mandement de Limperiale Maieste (Louvain: van Sassen, 1546), sigs. B[i $]^{\mathrm{r}}-\mathrm{Bii}^{\mathrm{r}}$. The punishment for an admitted printer breaching the ordinance was, by the letter at least, death and loss of all privileges (to avoid heritable value). The circumstances do not suggest bureaucratic delay, such as mentioned by Plantin rather later and under very different conditions (see Correspondance de Christophe Plantin, 4: 190-191, no. 579, dated 31 October 1574). Had this been the usual timescale, Susato would have known to date his edition later to avoid the appearance of flouting the regulations, especially after his recent difficulties with the authorities. However, Plantin's letter confirms that printers were extremely careful, at least later, to have their specific privileges in hand before beginning production.

48 Earlier, Susato seems to have relied heavily on the Imperial chapel as a source of repertory; see Ham, 'Crecquillon'.

49 For a brief description, see Strong, Art and Power, 89-90.

50 Discussed in Schiltz, Music and Riddle Culture, 351-358.

51 PL-Kj has a complete set (Mus. ant. pract. 1811) which, from information kindly supplied by the library, appears to be from the same edition as the tenor partbook in GB-Lbl.

52 Although inking and impression can lead to apparent variations even within a single book, the blocks appear sufficiently often in these and later editions to rule out such factors.

53 Forney, 'Tielman Susato', 109, 129, identifies it as Italic 13 from Vervliet, Sixteenth-Century Printing Types, 306-307. Forney gives the twenty-line measure of solid type as $70 \mathrm{~mm}$. My measurement of Susato's pica italic, taken over three different books, averages $82 \mathrm{~mm}(80 \mathrm{~mm}$ based on the longest ascenders/descenders). Besides individual letter forms that are quite distinct, the proportions of the Steelsius fount are noticeably different. (Examples can be compared online in the digital library of D-Mbs.) Forney provides no reconciliation between her identification and date of the fount and her dating of the second edition.

54 The explicits to TS 13 show that Susato originally began printing it as his twelfth book, but TS 12 leapfrogged it during production. Incorrect explicits in TS 13 (S/T/Q) were not simply carried over in error from TS 12; they are distinct. What might have led Susato to delay its completion is unclear. Evidence from earlier books suggests that the sheet bearing the dedication was often printed last. Here that voice, the bassus, carries no date on the title page or on the dedication itself. If there had been problems with securing his patronage, the printed date could conceivably be too early.

55 The fount used for an individual signature in the EC books was occasionally varied between Basel and pica italics to facilitate placing the furniture in the chase. The variants here are far more extensive and seemingly unrelated to a practical matter such as this, and with a fount not elsewhere used.

$56 \operatorname{TS~}^{\beta}(\mathrm{GB}-\mathrm{Lbl})$, gathering $\mathrm{C}$ in the contratenor book comes from the first edition of 1544 .

57 The distribution of type after EC 9 of 1554 also suggests that Susato needed it for other things before he went on to print EC 10-11.

58 Much of the title page for $S L 1-3$ was in common, but not transferred to $S L 4$. The single surviving exemplar of SL 4 may represent a different edition; alternatively, Susato may have interrupted the printing of the set to produce other books. Given his general practice, the former possibility seems more probable.

59 See note 29; to anticipate later discussion, aspects of Susato's hidden editions lead me to conclude that a degree of financial chicanery or manipulation was involved.

\section{References}

Becker, Georges. 'Goudimel et son oeuvre'. Bulletin historique et littéraire, Société de l'histoire du protestantisme français 34 (1885): 337-360.

Bernet Kempers, Karel P. ‘Die Sigel RISM $1553^{11}$ und $1553^{16}$. Fontes Artis Musicae 15 (1968): 108-110. 
Brown, Howard M. 'Review of Ute Meissner, Der Antwerpener Notendrucker Tylman Susato (Berlin: Verlag Merseburger, 1967)'. Journal of the American Musicological Society 21/2 (1968): 215-217.

Cardamone, Donna G. and David L. Jackson. 'Multiple Formes and Vertical Setting in Susato's First Edition of Lassus's “Opus 1"'. Notes 46/1 (1989): 7-24.

Clemens non Papa: Omnia opera, edited by Karel P. Bernet Kempers. Corpus Mensurabilis Musicae 4/13. s.l.: American Institute of Musicology, 1966.

Correspondance de Christophe Plantin. Vol. 4 edited by Jan Denucé. Antwerp: De Nederlandsche Boekhandel, 1914.

Dehnert, Lon T. 'Libri ecclesiasticarum cantionum (1553-60) of Tielman Susato: Review, Indexes, Examples by Willaert and Castileti'. DMA dissertation, University of Kansas, 1987.

A Dictionary of Superstitions, edited by Iona Opie and Moira Tatem. Oxford: Oxford University Press, 1989.

Fallows, David. 'The Printed Songbook at Kampen'. In NiveauNischeNimbus. Die Anfänge des Musikdrucks nördlich der Alpen, edited by Birgit Lodes. Wiener Forum für ältere Musikgeschichte 3. Tutzing: Schneider, 2010, 347-354.

Forney, Kristine K. 'New Insights into the Career and Musical Contributions of Tielman Susato'. In Tielman Susato and the Music of His Time, edited by Keith Polk. Hillsdale, NY: Pendragon Press, $2005,1-44$.

Forney, Kristine K. 'Orlando di Lasso's “Opus 1"': The Making and Marketing of a Renaissance Music Book'. Revue belge de musicologie 39/40 (1985/1986): 33-60.

Forney, Kristine K. 'Tielman Susato, Sixteenth-Century Music Printer: An Archival and Typographical Investigation'. PhD dissertation, University of Kentucky, 1978.

Goovaerts, Alphonse. Histoire et bibliographie de la typographie musicale dans les Pays-Bas. Antwerp: Pierre Kockx, 1880.

Ham, Martin. 'Crecquillon and the Printer Susato'. In Beyond Contemporary Fame: Reassessing the Art of Clemens non Papa and Thomas Crecquillon, edited by Eric Jas. Turnhout: Brepols, 2006, 27-46.

Horstmann, Angelika. Katalog der Musikdrucke aus der Zeit der Kasseler Hofkapelle (1550-1650). Wiesbaden: Harrassowitz Verlag, 2005.

Meissner, Ute. Der Antwerpener Notendrucker Tylman Susato. Berlin: Verlag Merseburger, 1967.

Milsom, John. 'The Nonsuch Music Library'. In Sundry Sorts of Music Books. Essays on The British Library Collections Presented to O. W. Neighbour on His 70th Birthday, edited by Chris Banks, Arthur Searle and Malcolm Turner. London: The British Library, 1993, 146-182.

Schiltz, Katelijne. Music and Riddle Culture in the Renaissance. Cambridge: Cambridge University Press, 2015.

Strong, Roy. Art and Power: Renaissance Festivals 1450-1650. Woodbridge: Boydell \& Brewer, 1984.

Thompson, Glenda Goss. 'Henry Loys and Iehan de Buys, Printers of Music in Antwerp'. Tijdschrift van de Vereniging voor Nederlandse muziekgeschiedenis 32, 1/2 (1982): 105-115.

Vervliet, Hendrik D. L. Sixteenth-Century Printing Types of the Low Countries. Amsterdam: Menno Hertzberger \& Co., 1968. 